\title{
Serum C - Reactive Protein Level and Peripheral Blood Picture in Children with Pneumonia
}

\author{
IGL Sidiartha, BNP Arhana, P Suwendra, Sudaryat S \\ Department of Child Health, Medical School, University of Udayana - Sanglah \\ General Hospital, Denpasar
}

\begin{abstract}
This cross sectional study aimed to determine the relation between serum C-reactive protein (CRP) levels and peripheral blood picture in children with bronchopneumonia, conducted at the Division of Pulmonology, Sanglah Hospital, Denpasar during 3 months (December 1996 to February 1997). Serum CRP levels, hemoglobin, leukocyte count, neutrophil count and ESR values in 30 cases between 1 month and 4.5 years (20 male and 10 female) were measured. Bronchopneumonia was mostly found in $<1$ year old $(67 \%)$ and with male to female ratio of $2: 1$. High CRP serum level $(>12 \mathrm{microgram} / \mathrm{ml}$ ) was found in $33 \%$ of 30 cases. Anemia was found in $37 \%$, leukocytosis in $50 \%$, increase segment neutrophil ratio in 30\%, increase of ESR in $40 \%$ and increase of body temperature more than $38^{\circ} \mathrm{C}$ in $47 \%$ of the cases. Neutrophilia, increase of ESR and increase of body temperature were found statistically significant difference between the positive CRP and negative CRP group. Most bronchopneumonia patients in this study were probably caused by non bacteria. Neutrophilia, higher ESR and higher body temperature could be used as an indicator of bacterial infection besides the increase of serum CRP levels. [Paediatr Indones 1998; 38: 62-67]
\end{abstract}

\section{Introduction}

Bronchopneumonia is one of the acute lower respiratory tract infections commonly found among children admitted to Pulmonology Division, Department of Child Health, Medical School, University of Udayana, Sanglah General Hospital, Denpasar. During 
5 -year period (1991 to 1995 ) there were 1149 cases $(12.8 \%)$ of bronchopneumonia and this disease as the second position of the big-ten diseases after diarrhea. ${ }^{1}$ In children, most of the infections were of viral origin, besides bacterial and other microorganisms. ${ }^{2}$ The etiologic diagnosis of bronchopneumonia is made by the detection of infecting agent. ${ }^{2,3}$ Despite the importance of etiologic diagnosis, this procedure is expensive and difficult to perform.

Serum CRP level, an acute-phase response by hepatic origin, may be used as an indicator for infection, and in a doubtful cases can be used to differentiate bacterial from viral infection. ${ }^{4.8}$ In bacterial infection the increase of serum CRP level can be $10 \mu \mathrm{g} / \mathrm{ml}$ or more, while in viral infection usually less than $10 \mu \mathrm{g} / \mathrm{ml} .^{4.8}$ The leukocyte count and ESR value can also be used as an indicator for bacterial infection, but serum CRP is more sensitive than this. ${ }^{1,7,8}$ Although it cannot be a substitute for an isolation technique in the etiologic diagnosis, measurement of serum CRP level offers more advantages in establishing the etiologic diagnosis. The purpose of this study was to describe serum CRP levels and peripheral blood picture in patients with bronchopneumonia.

\section{Methods}

This study was conducted in all babies and children with bronchopneumonia admitted to the Division of Pulmonology, Department of Child Health, Medical School, University of Udayana/Sanglah General Hospital, Denpasar from December 1996 to February 1997. The diagnosis of bronchopneumonia was based on clinical manifestations, i.e., acute fever, dyspnea with an increased respiratory rate, and suprasternal, intercostal, and epigastric retractions accompanied by rales on auscultation and supported by chest X-ray.

History of the illness, physical examination and supportive examinations were obtained in all cases. Patients with tuberculosis and other infections were excluded from this study. The peripheral blood picture was measured by automatic instruments (Cell Dyn 3000, Abbot). Normal values were based on hematological values as defined in babies and children. ESR was determined by Westergren method (normal: 10-15 mm/ hour). All routine laboratory findings were performed at the Laboratory of Sanglah General Hospital, Denpasar.

Serum CRP analysis was done only once, i.e. on admission, by using The Human CRP Latex Test with the qualitative-semiquantitative method. Qualitative method was performed by using a mixture of one drop of patient's serum added with one drop of The Human CRP Latex Test. Test was considered positive if the clotting was formed. Positive patient's serum than added with CRP glycine buffer as a solution 1:20, 1:40, 1:80 etc. Semi-quantitative method was done to estimate the concentration of serum CRP. Serum CRP concentration was estimated $12 \mu \mathrm{g} / \mathrm{ml}$ if the positive test was 
obtained from the mixture of patient's serum with glycine buffer $1: 40$, it was $24 \mu \mathrm{g} / \mathrm{ml}$ if positive test was obtained from dilution of $1: 80$, etc. Positive value was defined if the level was $12 \mu \mathrm{g} / \mathrm{ml}$ or more, and it was negative if the level was less than $12 \mu \mathrm{g} / \mathrm{ml}$ or more, and it was negative if the level was less than $12 \mu \mathrm{g} / \mathrm{ml}$. This analysis was performed in the Laboratory of Child Health Department, Sanglah General Hospital, Denpasar. Chi-square test was used to determine the relation between serum CRP levels and peripheral blood picture

\section{Results}

During the study, 30 cases of bronchopneumonia were included. Most patients $(20$ or $67 \%$ ) were less than 1 year of age, 9 patients $(30 \%)$ were between 1 and 3 years. The male to female ratio was 2:1 (Table 1).

Table 1. Characteristics of patients with bronchopneumonia

\begin{tabular}{crrr}
\hline $\begin{array}{c}\text { Age group } \\
\text { (year) }\end{array}$ & Male & Female & Total $(\%)$ \\
\hline $0-1$ year & 14 & 6 & $20(67)$ \\
$1-3$ years & 5 & 4 & $9(30)$ \\
$3-5$ years & 1 & 0 & $1(3)$ \\
\hline Total $(\%)$ & $20(67)$ & $10(33)$ & $30(100)$ \\
\hline
\end{tabular}

Serum CRP levels were $12 \mu \mathrm{g} / \mathrm{ml}$ or more (positive test) in 10 cases (33\%.) Peripheral blood analysis showed that hemoglobin level was normal in 19 cases $(63 \%)$, while leukocyte was more than normal in 15 cases $(50 \%)$ with neutrophilia in 9 cases $(30 \%)$. ESR value was increased in 12 cases $(40 \%)$; body temperature on admission was $38^{\circ} \mathrm{C}$ or more in 14 cases ( $47 \%$ ).

Leukocyte counts in peripheral blood were not significantly different between the groups of CRP level; however it was found that cases with CRP levels of $12 \mu \mathrm{g} / \mathrm{ml}$ or more were seen more with leukocytosis in 8 cases $(27 \%)$ compared with 7 cases $(23 \%)$ in CRP test negative. Segmental neutrophil counts more than normal, increased ESR levels and increased body temperature $38^{\circ} \mathrm{C}$ or more were seen significantly different between the two groups of CRP levels. 
Table 2. Association of peripheral blood picture, ESR, body temperalure and CRP level

\begin{tabular}{|c|c|c|c|}
\hline & \multicolumn{2}{|c|}{ CRP level } & \\
\hline & $\begin{array}{l}\text { Positive } \\
(n=10)\end{array}$ & $\begin{array}{c}\text { Negative } \\
(n=20)\end{array}$ & \\
\hline $\begin{array}{l}\text { Hemoglobin } \\
\text { - < normal } \\
\text {. normal }\end{array}$ & $\begin{array}{l}5 \\
5\end{array}$ & $\begin{array}{r}6 \\
14\end{array}$ & $p<0.05$ \\
\hline $\begin{array}{l}\text { WBC } \\
=>\text { normal } \\
=\text { normal }\end{array}$ & $\begin{array}{l}8 \\
2\end{array}$ & $\begin{array}{r}7 \\
13\end{array}$ & $p>0.05$ \\
\hline $\begin{array}{l}\text { Neutrophil } \\
=>\text { normal } \\
=\text { normal }\end{array}$ & $\begin{array}{l}7 \\
3\end{array}$ & $\begin{array}{r}2 \\
18\end{array}$ & $p<0.05$ \\
\hline $\begin{array}{l}\text { ESR } \\
\text { a >normal } \\
\text { = normal }\end{array}$ & $\begin{array}{l}8 \\
2\end{array}$ & $\begin{array}{r}4 \\
16\end{array}$ & $p<0.05$ \\
\hline $\begin{array}{c}\text { Temperature } \\
=>38^{\circ} \mathrm{C} \\
=<38^{\circ} \mathrm{C}\end{array}$ & $\begin{array}{l}8 \\
2\end{array}$ & $\begin{array}{r}6 \\
14\end{array}$ & $p<0.05$ \\
\hline
\end{tabular}

\section{Discussion}

$\mathrm{CRP}$ is an acute-phase response of hepatic origin as a reaction to inflammatory process that caused by bacterial or viral infection. Increased serum CRP could be detected in the blood about 6 to 12 hours after evident of the infection. This increase is varied, but many studies find that bacterial infection is usually associated with higher increase of serum CRP $\left(12 \mu \mathrm{g} / \mathrm{ml}\right.$ or more) then in viral infection. ${ }^{5,8,10 \cdot 12}$ This makes measurement of serum CRP valuable in distinguishing bacterial from viral infection.

In this study, we found the increase of serum CRP 12 microgram $/ \mathrm{ml}$ or more in 10 cases $(33 \%)$. This suggests that in our department, most bronchopneumonia cases were caused by viral infection. This finding was consistent with many reports.

Anemia may accompanies many infectious diseases, especially in chronic patients. This is caused by anorexia and as the consequence of direct hematopoetic cells damage by the agent or its product or autoimmune mechanism..$^{3.14}$ In this study, anemia was seen in 11 cases (37\%). The exact cause of anemia in this series was uncertain because the condition was influenced by many factors, including malnutrition which 
had occurred before the infection. The increase in leukocyte count with the shift to the left indicated the presence of bacterial infection, while normal or decreased count may be an indication of viral infection. ${ }^{3}$ In this series, leukocytosis was found in 15 cases $(50 \%)$; there was no statistically significant difference in leukocytosis between patients with positive and negative CRP group.

Neutrophil count was more specific indicator for bacterial infection than total leukocyte count. In this study, neutrophilia was found in 9 cases $(30 \%)$. There was a statistically significant difference of the proportion of neutrophilia between group with $\mathrm{CRP}>12 \mu \mathrm{g} / \mathrm{ml}$ and group with $\mathrm{CRP}<12 \mu \mathrm{g} / \mathrm{ml}$. ESR may also be used as an indicator for bacterial infection, although not as good as serum CRP. ${ }^{8}$ In this study, increased ESR was found in 12 patients $(40 \%), 8$ of them had a positive CRP test. There was a statistically significant association of increased ESR and positive CRP test $(p<0.01)$.

Elevated body temperature is found both in bacterial and viral infections. In bacterial infection, fever tends to be higher than in viral infection. In this series, fever of $38^{\circ} \mathrm{C}$ or more was found in 14 cases $(47 \%$,) and there was a statistically significant difference between the positive CRP and negative CRP test $(\mathrm{p}<0.05)$.

In conclusion, this series suggests that most bronchopneumonia in our hospital are caused by non bacterial infection. Increase of CRP, neutrophilia, increased of ESR and body temperature could be used as an indicator of bacterial infection.

\section{References}

1. Registrasi rawat inap ruang Jempiring dan Pudak RSUP Sanglah Denpasar.

2. Said M. Pneumonia dan bronkiolitis pada anak sebagai manifestasi infeksi saluran pernapasan akut berat. Dalam: Rahajoe $\mathrm{N}$ dkk. ed. Perkembangan dan masalah pulmonologi anak saat ini. Jakarta. Balai Penerbit FKUI 1994: 143-60,

3. Firdaus, Abubakar A, Saing LP, Daulay RM, Lubis H, Siregar Z. Serum C-reactive protein and peripheral blood picture in children with bronchopneumonia. Paediatr Indones 1995;35: 268-73.

4. Netteke, Rietveld A, Moolenaar A, Bel FV. Influence of perinatal conditions on C-reactive protein production. J Pediatr 1992;120: 621-4.

5. Ruuskanen O, Putto A, Sarkinen H, Meurmann O, Irjala K. C-reactive protein in respiratory virus infection. J Pediatr 1985;107: 97-100.

6. C-reactive protein (CRP) - How much proof do we need? Lab. Report 1994;16;11:83-5,

7. Corrall CJ, Pepple JM, Moxon ER, Hughes WT. C-reactive protein in spinal fluid of children with meningitis. Pediatries 1981;3:365-69.

8. Hart WR. C-reactive protein: the best laboratory indicator available for monitoring disease activity, Cleve Clin J Med 1989;56:126-30.

9. Human Gesellschaft fur Biochemica und Diagnostica GmbH.

10. Morley JJ, Kushner. Serum C-reactive protein levels in disease. 
11. Peltola H, Jaakhola M. C-reactive protein in early detection of bacteremic versus viral infections in immunocompetent and compromised children. J Pediatr 1988:641-6.

12. Beckman. Quantitative C-reactive protein (CRP) assay information for the children. PACE (Pointer to Approach Confidence \& Excellence) 1994;17: 2.1-4.1.

13. Kilham H. Haematological and biochemical standards. In: Kilham H, ed. The Children's Hospital Handbook. Australia: Alken Press Pty Ltd 1988: 11-21.

14. Kresno SB. Pengantar Hematologi dan Imunohematologi. Jakarta: FKUI 1988. 